\title{
Production performance of pigs reared in different systems and fed increased energy content diets with or without green alfalfa
}

\author{
W.J. Kozera\#, K. Karpiesiuk, D. Bugnacka, J. Falkowski \& W. Milewska \\ Department of Pig Breeding, University of Warmia and Mazury, 10-718 Olszlyn, Oczapowskiego 5, Poland
}

(Received 23 November 2015; Accepted 27 January 2016; First published online 13 March 2016)

\begin{abstract}
Copyright resides with the authors in terms of the Creative Commons Attribution 2.5 South African Licence.
See: http://creativecommons.org/licenses/by/2.5/za

Condition of use: The user may copy, distribute, transmit and adapt the work, but must recognise the authors and the South African Journal of Animal Science.
\end{abstract}

\begin{abstract}
The objective of this study was to determine the effects of various feeding and housing systems on fattening performance, slaughter value and biochemical serum parameters in growing-finishing pigs. The experimental material comprised 90 growing-finishing pigs, divided into six groups of 15 animals that were diverse in terms of rearing (with or without free access to outdoor runs) and feeding systems (fed increased metabolizable energy (ME) content diets with or without green alfalfa). Different feeding regimes and rearing systems had no significant effects on most fattening results and the carcass traits of the pigs except for daily water and diet intake and feed/gain ratio. Daily water intake was lower in pigs fed complete diets plus green alfalfa forage. Low-density lipoprotein (LDL) cholesterol concentrations were statistically lower in the blood serum of Groups 3 and 6 than in Groups 2 and 4. High-density lipoprotein (HDL) cholesterol levels were significantly higher in the serum of Group 6, compared with other groups. Group 3 had significantly higher triglycerides levels compared with Groups 1, 2, 4, 5 and 6. Taking into consideration all these dependencies, it could be assumed that feeding regime and rearing with access to outdoor runs might improve not only blood lipid profile, but also the dietetic value of pork. It seems that feeding a complete diet with increased ME, plus green alfalfa forage and rearing indoors with free access to outdoor runs, gave the best results.
\end{abstract}

\footnotetext{
Keywords: Carcass quality, finishing system, lipids, pig nutrition, production system

\#Corresponding author: kozwoj@uwm.edu.pl
}

\section{Introduction}

In recent years the dramatic shift in availability of feed ingredients for the pig industry has meant that a wider range of feedstuffs must be considered in formulating pig diets, including those that contain considerable amounts of fibre. Because energy is the single most expensive component of a pig diet, optimizing its utilization is critical for efficient pork production (Velayudhan et al., 2015).

Numerous studies worldwide have attempted to compare the growth performances of pigs kept indoors with outdoor production systems, but their results have been inconclusive and, in many cases, contradictory (Lebret, 2008; Lebret et al., 2014). In a study by Gentry et al. (2002), pigs reared outdoors were characterized by higher growth rates than pigs born and finished in an indoor environment. Similar trends were noted by Stern et al. (2003) and Millet et al. (2005). In another experiment (Gentry et al., 2004), pigs reared outdoors were heavier and had higher gain/feed ratios. Different results were reported by Hoffman et al. (2003) and Enfält et al. (1997), who noted higher daily gains in pigs kept indoors. According to other authors (Sather et al., 1997; Stern et al., 2003; Lebret, 2008; Lebret et al., 2014), free-range pigs needed a longer period to reach the desired market weight, and used their feed less efficiently.

These results suggest that the effects of diets that differ in energy concentration should be analysed, because pigs reared indoors and those raised outdoors (with access to open-air runs or pasture) differ in their protein and energy requirements because free-range pigs use more energy owing to more extensive physical activities and the need to maintain body temperature during cold periods. There are still divergences in the results of many studies about the influence of rearing conditions and feeding regime on carcass traits and quality of pig meat (Enfält et al., 1997; Klont et al., 2001; Millet et al., 2005; Jordan et al., 2008; Lebret, 2008; Karpiesiuk et al., 2013; Lebret et al., 2014).

Taking these aspects into account, it is worth remembering that there has been increasing interest in alternative pig feeding and housing systems in recent years. Farming practices of environmental enrichment 
are methods of improving animal welfare and increasing disease resistance (Klont et al., 2001; Gentry et al., 2002; 2004) as well as supporting the production of organic, health-promoting foods with high nutritional value, in response to growing consumer demands (Kozera, 2007).

The objective of this study was to determine the effects of various feeding systems (addition of green alfalfa forage, increased metabolizable energy content) and housing (indoors or indoors with free access to outdoor runs) on fattening performance, slaughter value and biochemical serum parameters in growingfinishing pigs.

\section{Materials and Methods}

The experimental material comprised 90 growing-finishing pigs produced by mating (Polish Large White $x$ Polish Landrace) sows with (Duroc $x$ Pietrain) boars. The pigs were randomly allocated to six experimental groups of 15 animals (5 pigs/pen) based on their initial bodyweights, sex ( 7 barrows and 8 gilts/group) and origin of litter (piglets from 24 litters): Group 1 was fed a complete diet and kept indoors with free access to outdoor runs; Group 2 was fed a complete diet and was kept indoors; Group 3 was fed a complete diet with an increased ME content and was kept indoors with free access to outdoor runs; Group 4 was fed a complete diet plus green alfalfa forage, and was kept indoors with free access to outdoor runs; Group 5 was fed a complete diet plus green alfalfa forage, and was kept indoors and Group 6 was fed a complete diet with increased ME content, plus green alfalfa forage, and was kept indoors with free access to outdoor runs. Pigs of all experimental groups were located in the same location and were kept in pens $(3 \mathrm{~m} \times 3 \mathrm{~m})$ without litter. The experiment was conducted from May to August, that is in summer.

Animals of Groups 1, 2, 4 and 5 received complete control cereal-soybean diets (Table 1), formulated in accordance with Pig Nutrient requirements (1993) for one-phase feeding (from $30 \mathrm{~kg}$ to $110 \mathrm{~kg}$ Rbodyweight), offered ad libitum from automatic feeders. Pigs of Groups 3 and 6 were fed the complete experimental diets in which the concentration of ME was increased by $10 \%$ (by adding rapeseed oil) relative to the control diet used in pigs feeding in other groups (i.e. Groups 1, 2, 4 and 5). Pigs in Groups 4,5 and 6 were fed additional green alfalfa forage ( $3 \mathrm{~kg}$ per pen), offered once a day at 08:00 in stoneware troughs.

The experiment started when the pigs reached an average initial bodyweight of $28.5 \mathrm{~kg}$, and was carried out for 122 days to the average final bodyweight of $118.5 \mathrm{~kg}$. Feed intake, green alfalfa forage consumption and water intake from nipple drinkers were monitored throughout the experiment. The chemical composition of experimental diets and green alfalfa forage was determined by AOAC (2006) methods. In order to determine the effects of feeding regimes and housing systems on the lipid profile, blood was sampled from all the pigs (from vena cava cranialis) a week before expected slaughter. The serum levels of total cholesterol, HDL cholesterol, LDL cholesterol, triglycerides and cortisol were determined. All analyses were performed with the Cobas Integra 800 analyzer (protein was determined by the biuret assay, urea by the kinetic test with urease and glutamate dehydrogenase, total cholesterol and triglycerides by enzymaticcolorimetric methods, HDL cholesterol by an enzymatic colorimetric test. LDL cholesterol levels were calculated based on Friedewald formula (Friedewald et al. 1972).

Table 1 Composition of experimental diets

\begin{tabular}{lcc}
\hline & \multicolumn{2}{c}{ Complete diets } \\
\cline { 2 - 3 } Specification & $\begin{array}{c}\text { Control } \\
\text { (Groups 1, 2, 4 and 5) }\end{array}$ & $\begin{array}{c}\text { Experimental } \\
\text { (with increased ME level) } \\
\text { (Groups 3 and 6) }\end{array}$ \\
\hline Ground wheat & 40.00 & 40.00 \\
Ground barley & 44.88 & 39.88 \\
Soybean meal & 12.00 & 13.00 \\
Rapeseed oil & - & 4.00 \\
Premix* & 3.00 & 3.00 \\
L-lysine & 0.12 & 0.12
\end{tabular}

*Composition of premix: 341600 j.m.vitamin A; 54165 j.m.vitamin $\mathrm{D}_{3} ; 2166 \mathrm{mg}$ vitamin $\mathrm{E} ; 75 \mathrm{mg}$ vitamin $\mathrm{K}$; $37.5 \mathrm{mg}$ vitamin $\mathrm{B}_{1} ; 116.6 \mathrm{mg}$ vitamin $\mathrm{B}_{2} ; 66.6 \mathrm{mg}$ vitamin $\mathrm{B}_{6} ; 0.58 \mathrm{mg}$ vitamin $\mathrm{B}_{12}: 600 \mathrm{mg}$ vitamin $\mathrm{B}_{3} ; 275.8$ $\mathrm{mg}$ pantothenic acid; $10 \mathrm{mg}$ folic acid; $10000 \mathrm{mg}$ choline chloride; $1.33 \mathrm{mg}$ vitamin $\mathrm{H} ; 3000 \mathrm{mg} \mathrm{Fe;} 700 \mathrm{mg}$ Cu; 3666 mg Zn; 2000 mg Mn; 5.33 mg Se; 13.3 mg I; 8.33 mg Co; 5 mg Mg; 33.3 g Na; 40 g P; 226 g Ca; $61.66 \mathrm{~g}$ lysine; $8.33 \mathrm{~g}$ methionine; $9.16 \mathrm{~g}$ threonine. ME: metabolizable energy. 
Slaughter, post-slaughter processing and carcass evaluation were carried out in accordance with meat industry regulations. Lean meat content was determined on suspended hot right half-carcasses, using the CGM (Capteur Gras/Maigre) apparatus by Sydel, operated by authorized and trained personnel. CGM is a hand-held device equipped with an optical probe that determines the thickness of the loin muscle and the fat layer by measuring the light reflected in the probe. The device determines the lean meat content of the carcass, that is, the ratio of the total mass of the striated muscles to the mass of the carcass:

$$
\mathrm{LMC}_{\mathrm{CGM}}=59.42+0.1322 \mathrm{M}_{2}-0.6275 \mathrm{~T}_{2}
$$

$T_{2}$ is the thickness of the backfat between the 3rd and 4th ribs, $6 \mathrm{~cm}$ from the line of carcass partition; $M_{2}$ is the thickness of the longissimus dorsi muscle, $6 \mathrm{~cm}$ from the line of carcass partition. It is measured no longer than 45 minutes after the animal was stunned.

The $\mathrm{pH}$ was measured in the longissimus lumborum ( $\mathrm{LL}) 45$ min after bleeding $\left(\mathrm{pH}_{45}\right)$ and after 24 hours of carcass chilling $\left(\mathrm{pH}_{24}\right)$. The parameters, $\mathrm{pH}_{45}$ and $\mathrm{pH} 24$, were determined with the WTW $3310 \mathrm{pH}$ meter and combination electrode (WTW-Wissenschaftlich-Technische Werkstaetten GmbH, Weilheim, Germany) and calibrated with the same standard solutions of $\mathrm{pH} 4.01$ and 7.00 at $20^{\circ} \mathrm{C}$. Additionally, their accordance was tested with meat samples at the beginning of and regularly during the measuring period.

On cold carcasses, backfat thickness (BFT) (means of five measurements) was measured at five points with callipers: At the thickest point over the shoulder, on the back behind the last rib, over the cranial border of $m$. gluteus medius (loin I), over the centre of $m$. gluteus medius (loin II), over the caudal border of m. gluteus medius (loin III).

All parameters were processed statistically, and the significance of differences between means in groups was determined by two-way analysis of variance (ANOVA) and the Duncan's test. A two-way analysis was carried out in order to assess the significance of different feeding and rearing systems and was performed using the general lineal model (GLM) procedure of StatSoft software (version Statistica PL 12.5). The model of analysis was:

$$
Y_{i j k}=\mu+F T_{i}+R S_{j}+(F T \times R S)_{i j}+\varepsilon_{i j k}
$$

where $F T_{i}$ is the feeding type $(I=1,2,3), R S_{j}$ the rearing systems $(j=1,2),(F T \times R S)_{i j}$ the interaction between the feeding and rearing effects and $\varepsilon_{\mathrm{ijk}}$ is the residual error.

The experiment was approved by the local Ethics Committee for Animal Experimentation at Olsztyn.

\section{Results and Discussion}

Table 2 presents the chemical composition of experimental diets. The total protein content of the control and experimental diets was 165.6 and $163.0 \mathrm{~g} / \mathrm{kg}$, respectively, which meets the protein level specified for a one-phase feeding of growing-finishing pigs in the Pig Nutrient Requirements (1993). The ME content of diets, calculated from tabular data, was consistent with the methodological assumptions.

\begin{tabular}{|c|c|c|c|}
\hline \multirow{2}{*}{ Specification } & \multicolumn{2}{|c|}{ Complete diet } & \multirow{2}{*}{$\begin{array}{l}\text { Green alfalfa forage } \\
\quad(\text { Groups } 4,5,6)\end{array}$} \\
\hline & $\begin{array}{c}\text { control } \\
\text { (Groups } 1,2,4,5)\end{array}$ & $\begin{array}{l}\text { experimental } \\
\text { (Groups } 3,6 \text { ) }\end{array}$ & \\
\hline Dry matter & 88.83 & 89.26 & 18.40 \\
\hline Crude protein & 16.56 & 16.30 & 3.55 \\
\hline Crude fat & 1.65 & 5.27 & 0.39 \\
\hline Crude fibre & 4.41 & 4.08 & 5.52 \\
\hline Crude ash & 4.11 & 3.77 & 1.90 \\
\hline $\mathrm{ME}^{1} \mathrm{MJ} / \mathrm{kg}$ (calculated) & 12.72 & 13.84 & 8.80 \\
\hline $\mathrm{N}$-free extractives & 62.10 & 59.84 & 7.04 \\
\hline Organic matter & 84.72 & 85.49 & 16.50 \\
\hline
\end{tabular}

Table 2 Chemical composition of experimental diets and green alfalfa forage

\footnotetext{
${ }^{1}$ ME: metabolizable energy, calculated values (Pig Nutrient Requirements, 1993).
} 
Daily feed intake per pig was different between groups, ranging from $2.15 \mathrm{~kg}$ in Group 2 to $2.40 \mathrm{~kg}$ in Group 4. Significant differences were observed between all groups (Table 3). Average feed/gain ratio (i.e. $\mathrm{kg}$ of complete diet $/ \mathrm{kg}$ gain) was highly satisfactory, at 2.98, 2.93, 3.25, 3.19, 3.04 and $2.96 \mathrm{~kg}$ in groups $1-6$, respectively, whereas green alfalfa forage intake per $\mathrm{kg}$ bodyweight gain was $1.59 \mathrm{~kg}$ in Group 4, $1.68 \mathrm{~kg}$ in Group 5 and $1.67 \mathrm{~kg}$ in Group 6. Daily water intake was lower in pigs fed complete diets with an addition of green alfalfa forage, compared with animals fed complete diets (Table 3). Higher water intake was noted in Groups 1, 2 and 3, at 5.14, 5.48 and 4.95 L/head/day, respectively. In Groups 4, 5 and 6, fed green alfalfa forage as additional feed, water intake was $4.76,4.43$ and $4.34 \mathrm{~L} / \mathrm{head} /$ day, respectively. Differences between groups were statistically different $(P \leq 0.05,0.01)$.

Table 3 Average daily feed and water intake and feed/gain ratio of experimental pigs

\begin{tabular}{|c|c|c|c|c|c|c|c|c|c|}
\hline \multirow{2}{*}{ Specification } & \multicolumn{6}{|c|}{ Group (feeding/rearing) } & \multirow{2}{*}{ SEM } & \multicolumn{2}{|c|}{ Significance level } \\
\hline & 1 & 2 & 3 & 4 & 5 & 6 & & Rearing & Feeding \\
\hline $\begin{array}{l}\text { Daily intake of diets (kg of } \\
\text { mixture/pig) }\end{array}$ & $2.21^{\mathrm{B}}$ & $2.15^{\mathrm{BD}}$ & $2.31^{\mathrm{cb}}$ & $2.40^{\mathrm{Aa}}$ & $2.30^{\mathrm{B}}$ & $2.27^{\mathrm{B}}$ & 0.021 & NS & * \\
\hline Daily intake of alfalfa (kg/pig) & - & - & - & 0.47 & 0.43 & 0.46 & 0.010 & NS & NS \\
\hline Daily water intake (L/pig) & $5.14^{\mathrm{BCa}}$ & $5.48^{\mathrm{A}}$ & $4.95^{\mathrm{BbE}}$ & $4.76^{\mathrm{BDF}}$ & $4.43^{\mathrm{BDF}}$ & $4.34^{\mathrm{BDF}}$ & 0.097 & NS & ** \\
\hline $\begin{array}{l}\text { Feed/grain ratio (kg of mixture } \\
\text { /kg gain) }\end{array}$ & $2.98^{\mathrm{B}}$ & $2.93^{\mathrm{Bb}}$ & $3.25^{\mathrm{A}}$ & $3.19^{\mathrm{A}}$ & $3.04^{\mathrm{Ba}}$ & $2.96^{\mathrm{B}}$ & 0.031 & NS & * \\
\hline $\begin{array}{l}\text { Feed/gain ratio (kg alfalfa/kg } \\
\text { gain) }\end{array}$ & - & - & - & 1.59 & 1.68 & 1.67 & 0.021 & NS & NS \\
\hline
\end{tabular}

Means within rows followed by different letters or * are different in the Duncan test: * a b, c d: $P \leq 0.05 ;{ }^{* *} A B, C D$, E F: $P \leq 0.01$; NS: not significant.

Water intake was lower in pigs fed alfalfa (Groups 4, 5 and 6) as green forage provides some of the daily water requirements. These data corroborate the findings of Karpiesiuk \& Falkowski (2008), who noted water intakes of $4.82 \mathrm{~L}$ to $6.36 \mathrm{~L}$ in groups that had no access to green forage and $3.39 \mathrm{~L}$ to $4.48 \mathrm{~L}$ in groups fed green alfalfa as an additional feed. Gadd (2005) reported that water requirements of pigs with different body weights (BW) were 15 - $40 \mathrm{~kg} \mathrm{BW:} 2.25$ L/day/head; 40 - $60 \mathrm{~kg} \mathrm{BW:} 5.00 \mathrm{~L} /$ day/head; $60 \mathrm{~kg}$ BW and above: $6.00 \mathrm{~L} / \mathrm{day} / \mathrm{head}$. According to the guidelines of the nutrient requirements of swine (NRC, 2012), the water requirements of growing pigs fed ad libitum are ca. $2 \mathrm{~L}$ per $\mathrm{kg}$ feed.

The average values of pig serum biochemical parameters of pigs are shown in Table 4. No significant differences in total cholesterol concentrations were found between groups, and the average level of this compound ranged from $2.24 \mathrm{mmol} / \mathrm{L}$ (Group 6) to $2.04 \mathrm{mmol} / \mathrm{L}$ (Group 4).

The feeding regimes and housing systems contributed to highly significant and significant differences in HDL cholesterol, LDL cholesterol and triglycerides concentrations among groups. The level of HDL cholesterol was highest in pigs reared outdoors and fed the complete experimental diet (with increased ME level) plus green alfalfa forage $(1.25 \mathrm{mmol} / \mathrm{L})$. It was confirmed statistically on a high significant level $(P$ $\leq 0.01)$ compared with Groups 1, 2, 4 and 5 and on a significant level $(P \leq 0.05)$ in Group $3(1.11 \mathrm{mmol} / \mathrm{L})$. At the same time, the lowest level of LDL cholesterol was noted in Group $3(0.77 \mathrm{mmol} / \mathrm{L})$ and this value was statistically differentiated from Groups $2(P \leq 0.01)$ and $4(P \leq 0.05)$. Group 3 had significantly higher triglycerides levels $(0.65 \mathrm{mmL} / \mathrm{L})$, compared with Groups $1,2,4,5$ and 6 , where these values were noted, namely $0.35,0.33,0.26,0.33$ and $0.43 \mathrm{mmL} / \mathrm{L}$, respectively. Significant differences were observed between Groups $6(0.43 \mathrm{mmL} / \mathrm{L})$ and $4(0.26 \mathrm{mmL} / \mathrm{L})$. There were no statistically confirmed differences in cortisol level between animals of experimental groups.

Blood cholesterol levels are determined by genetic factors and environmental conditions, including nutrition (Hanczakowski et al., 2009). In the present study, total cholesterol concentrations were slightly above the reference range (Winnicka, 2011) in Groups 2, 3 and $6(2.19 \mathrm{mmol} / \mathrm{L}, 2.14 \mathrm{mmol} / \mathrm{L}$ and 2.24 $\mathrm{mmol} / \mathrm{L}$, respectively). Migdał et al. (1999) reported a rising tendency in concentrations of lipids and cholesterol in the serum (including LDL) of meat-type crossbred pigs. Differences between groups, confirmed by statistical analysis, were noted for HDL and LDL cholesterol concentrations. According to Winnicka (2011), levels of HDL cholesterol in pig serum should account for at least $40 \%$ of total cholesterol concentrations, since a decrease in the HDL fraction below this value is undesirable. In the current study, the 
Table 4 Serum biochemical parameters of experimental pigs

\begin{tabular}{|c|c|c|c|c|c|c|c|c|c|}
\hline \multirow{2}{*}{ Specification } & \multicolumn{6}{|c|}{ Group (feeding/rearing) } & \multirow{2}{*}{ SEM } & \multicolumn{2}{|c|}{ Significance level } \\
\hline & 1 & 2 & 3 & 4 & 5 & 6 & & Rearing & Feeding \\
\hline Total cholesterol (mmL/L) & 2.05 & 2.19 & 2.14 & 2.04 & 2.07 & 2.24 & 0.026 & NS & * \\
\hline HDL cholesterol (mmL/L) & $1.01^{\mathrm{B}}$ & $1.05^{\mathrm{B}}$ & $1.11^{\mathrm{b}}$ & $1.00^{\mathrm{B}}$ & $1.01^{\mathrm{B}}$ & $1.25^{\mathrm{Aa}}$ & 0.020 & NS & ** \\
\hline LDL cholesterol (mmL/L) & 0.89 & $1.01^{\mathrm{Aa}}$ & $0.77^{\mathrm{Bd}}$ & $0.94^{c}$ & 0.93 & $0.81^{\mathrm{b}}$ & 0.023 & * & * \\
\hline Triglycerides (mmL/L) & $0.35^{\mathrm{B}}$ & $0.33^{\mathrm{B}}$ & $0.65^{\mathrm{A}}$ & $0.26^{\mathrm{Bb}}$ & $0.33^{\mathrm{B}}$ & $0.43^{\mathrm{Ba}}$ & 0.024 & * & $\star \star$ \\
\hline Cortisol $(\mu \mathrm{g} / \mathrm{dL})$ & 5.08 & 5.64 & 4.31 & 4.04 & 6.03 & 5.77 & 0.330 & NS & NS \\
\hline
\end{tabular}

Means within rows followed by different letters or * are different by the Duncan test: * a b, c d: $P \leq 0.05$.

** A B: $P \leq 0.01$; NS: not significant.

HDL fraction had a $47 \%$ to $55 \%$ share of total cholesterol.

In the blood serum of animals fed a complete diet supplemented with rapeseed oil (Groups 3 and 6), which contains a relatively high level of unsaturated fatty acids (PUFA/MUFA), a significant increase in the levels of HDL cholesterol and a decrease in the levels of LDL cholesterol were confirmed, compared with other the groups. The differences between the groups were statistically significant $(P \leq 0.05)$ or highly significant $(P \leq 0.01)$. Obtained dependencies confirmed the theory that PUFA/MUFA in animal food has an influence on the lipid profile of animals' blood serum (i.e. an increase in HDL and decrease in LDL cholesterol levels precisely) (Froyland et al., 1996; Barowicz \& Pietras, 1998). In addition, in the blood serum of the animals in Group 6, a statistically significant and higher level of HDL cholesterol was recorded compared with pigs of Group 3. This could be a positive result of the addition of green alfalfa as a forage feed in Group 3. It could be explained that a higher crude fibre level in the diet influences a growing level of $\mathrm{HDL}$ cholesterol. At the same time it induces a reduction in the LDL cholesterol level in blood serum. Such a dependence was noted in earlier studies (Kishimoto et al., 1995; Kozera et al., 2006; Hanczakowski et al., 2009). Taking into consideration all these dependencies (i.e. HDL and LDL levels), it could be assumed that feeding regime (diet with increased ME content from rapeseed oil supplementation and green alfalfa forage addition) and rearing conditions (with access to outdoor runs) might improve the dietetic value of meat. Demigne et al. (1995) stated that there is dependence between a cholesterol production in animals` livers and the dietetic value of pork.

With regard to triglycerides, Group 3 had significantly higher triglyceride levels compared with all other groups. In addition, significant differences were observed between Groups 6 and 4 for this parameter. It could be concluded that feeding growing-finishing pigs a diet with increased ME content had a significant influence on the serum triglycerides level. However, animals fed in this way, but with green alfalfa as additional forage (Group 6), had a significantly lower level of serum triglycerides compared with Group 4. This is in agreement with earlier investigations (Kozera et al., 2006), which proved that increased crude fibre levels in experimental diets resulted in an increase in triglycerides.

Serum cortisol is widely used as an indicator of stress (Choe et al., 2014). In the present study, the levels of this hormone were similar and not differentiated among groups. Nevertheless, there was a tendency to lower the level of cortisol serum in pigs reared with free access to outdoor runs compared with those reared indoors. It could be understood as a determinant of better welfare.

Animals of all experimental groups were characterized by similar initial bodyweights, which ranged from $28.1 \mathrm{~kg}$ in Group 6 to $28.9 \mathrm{~kg}$ in Group 3 (Table 5). At slaughter, pigs from Group 6 were heaviest $(121.8 \mathrm{~kg})$, while the Group 3 animals were lightest $(115.4 \mathrm{~kg})$. Higher daily gains were noted in Groups 4 $(751 \mathrm{~g})$ and $6(769 \mathrm{~g})$, and the lowest in Group $3(709 \mathrm{~g})$. Carcass quality parameters are presented in Table 5. Carcass dressing percentage was similar in all the groups, and all carcasses had a high average lean meat content, which was the highest in pigs reared indoors and fed complete diets plus green alfalfa forage, and lowest in pigs kept indoors and fed complete diets without green alfalfa forage as additional feed, but these differences were not confirmed statistically. No significant differences in loin eye area of LM, backfat thickness (BFT), the levels of $\mathrm{pH}_{45}$ and $\mathrm{pH}_{24}$ were found between the groups.

The growth rates of experimental pigs were similar to those reported by other authors. In a study by Høøk-Presto et al. (2009), the average daily gain of growing-finishing pigs was $740 \mathrm{~g}$. Karpiesiuk \& Falkowski (2008) obtained daily gains of growing-finishing pigs on a similar level to the present study, that is, on average $727 \mathrm{~g}$. 
Regarding slaughter traits, it could be concluded that types of feeding and rearing of growing-finishing pigs did not affect values of carcass traits between groups significantly. Strudsholm \& Hermansen (2005), working with crossbred animals [(Large White $\mathrm{x}$ Landrace) $\times$ Duroc], reported that pigs kept in confined system had a lower content of lean meat (on average 2.3\%) and higher backfat thickness (on average 1.1 $\mathrm{mm}$ ), compared with growing-finishing pigs reared in an outdoor system. In the results of studies by Parunović et al. (2012), the carcass weight and cold carcass yield percentage were lower in the free-range reared pigs than in those fed and reared conventionally. According to the authors, this could be explained by a type of feeding regime. That is, intake of grass fibre led to better development of the digestive system (mainly the large intestine). Finally, it must be stressed that according to meat classification based on $\mathrm{pH}_{24}$ (5.44 - 5.52), meat from the experimental pigs in the current study could be considered normal and was characterized as good quality.

Table 5 Fattening performance and slaughter value of experimental pigs

\begin{tabular}{|c|c|c|c|c|c|c|c|c|c|}
\hline \multirow{2}{*}{ Specification } & \multicolumn{6}{|c|}{ Group (feeding/rearing) } & \multirow{2}{*}{ SEM } & \multicolumn{2}{|c|}{ Significance level } \\
\hline & 1 & 2 & 3 & 4 & 5 & 6 & & Rearing & Feeding \\
\hline Initial bodyweight (kg) & 28.6 & 28.4 & 28.9 & 28.5 & 28.5 & 28.1 & 0.293 & NS & NS \\
\hline Final bodyweight (kg) & 118.9 & 118.1 & 115.4 & 120.2 & 116.7 & 121.8 & 1.166 & NS & NS \\
\hline Average daily gain (g) & 741 & 734 & 709 & 751 & 725 & 769 & 9.276 & NS & NS \\
\hline Carcass weight (kg) & 97.8 & 95.2 & 89.7 & 96.4 & 95.5 & 98.8 & 1.280 & NS & NS \\
\hline Dressing percentage (\%) & 78.7 & 79.2 & 78.5 & 79.9 & 79.1 & 79.8 & 0.285 & NS & NS \\
\hline Lean meat content (\%) & 55.6 & 54.2 & 55.1 & 55.6 & 56.0 & 54.5 & 0.379 & NS & NS \\
\hline Loin eye area $\mathrm{cm}^{2}$ ) & 62.4 & 58.9 & 56.1 & 63.7 & 59.7 & 65.3 & 1.058 & NS & NS \\
\hline Backfat thickness (mm) & 24.1 & 24.1 & 23.2 & 24.6 & 22.1 & 25.5 & 0.532 & NS & NS \\
\hline $\mathrm{pH}_{45}$ & 6.48 & 6.62 & 6.54 & 6.57 & 6.52 & 6.56 & 0.029 & NS & NS \\
\hline $\mathrm{pH}_{24}$ & 5.49 & 5.49 & 5.44 & 5.50 & 5.49 & 5.52 & 0.021 & NS & NS \\
\hline
\end{tabular}

NS: not significant.

\section{Conclusion}

Different feeding regimes and housing systems had no significant effect on the growth rate of pigs. The production results were highly satisfactory in all experimental groups. The addition of alfalfa green forage and/or supplementing the experimental diets with rapeseed oil resulted in increasing of the HDL cholesterol levels in the blood serum and decrease in the levels of LDL cholesterol in the blood, but had no significant influence on the blood level of total cholesterol. Cortisol levels in the serum were comparable in all groups (however, a little lower in pigs reared with access to outdoor runs), which indicates that pigs were provided with adequate nutrition and housing in all analysed systems. At the same time, this is a sign of good welfare status of growing-finishing pigs of all investigated groups. It seems that feeding a complete diet with increased ME content plus green alfalfa forage and being reared indoors with free access to outdoor runs gave the best results.

\section{Authors' contributions}

WJK and JF coordinated the project design and implementation. KK was in charge of sample collecting and with DB and WM was responsible for laboratory tests. All co-authors participated in results, statistics and interpretation. WJK was in charge of writing the manuscript.

\section{Conflict of interest declaration}

We wish to confirm that there are no known conflicts of interest associated with the publication of this manuscript and there has been no significant financial support for this work that could have influenced its outcome. We also confirm that this manuscript has been read and approved by all authors and that the order of authors listed in the manuscript has been approved by all of us.

\section{References}

AOAC, 2006. Official Methods of Analysis (18th ed.). Association of Official Analytical Chemists. Washington, D.C., USA. 
Barowicz, T. \& Pietras, M., 1998. Effect of dietary source of UFA and sex of animals on some lipid indices of blood of the longissimus dorsi muscle in pigs. Rocz. Nauk. Zoot. 25, 83-97. (in Polish, English abstract).

Choe, J.H., Choi, M.H., Ryu, Y.C., Lim, K.S., Lee, E.A., Kang, J.H., Hong, K.C., Lee, S.K., Kim, Y.T., Moon, S.S., Lee, K.W., Rhee, M.S. \& Kim, B.C., 2014. Correlations among various blood parameters at exsanguination and their relationships to pork quality traits. Anim. Prod. Sci. 55, 672-679.

Demigne, C., Morand, C., Levrat, M.A., Besson, C., Mundras, C. \& Remesy, C., 1995. Effect of propionate on fatty acid and cholesterol synthesis and on acetate metabolism in isolated rat hepatocyte. Br. J. Nutr. 74, 209-219.

Enfält, A.C., Lundström, K., Hansson, I., Lundeheim, N. \& Nyström, P.E., 1997. Effects of outdoor rearing and sire breed (Duroc or Yorkshire) on carcass composition and sensory and technological meat quality. Meat Sci. 45, 1-15.

Friedewald, W.T., Levy R.I. \& Fredrickson D.S., 1972. Estimation of concentration of low-density lipoprotein cholesterol in plasma, without use of the preparative ultracentrifuge. Clinical Chemistry 18, 499-502.

Froyland, L., Vaagenes, H., Asiedn, D.K. \& Garras, A., 1996. Chronic administration of eicosapentaenoic acid and docosahaexnoic acid as ethyl esters reduces plasma cholesterol and changed the fatty acid composition in rat blood and organs. Lipids 31, 169-178.

Gadd, J., 2005. Pig production. What the textbooks don't tell you. Nottingham University Press, UK.

Gentry, J.G., McGlone, J.J., Blanton, J.R. \& Miller, M.F., 2002. Alternative housing systems for pigs: Influence on growth, composition, and pork quality. J. Anim. Sci. 80, 1781-1790.

Gentry, J.G., McGlone, J.J., Miller, M.F. \& Blanton Jr., J.R., 2004. Environmental effects on pigs performance, meat quality, and muscle characteristics. J. Anim. Sci. 82, 209-217.

Hanczakowski, P., Szymczak, B. \& Hanczakowska, E., 2009. Fatty acid profile and cholesterol content of meat from pigs fed different fats. Ann. Anim. Sci. 9,157-163.

Hoffman, L.C., Styger, E., Muller, M. \& Brand, T.S., 2003. The growth and carcass and meat characteristics of pigs raised in a free-range or conventional system. S. Afr. J. Anim. Sci. 33, 166-175.

Høøk Presto, M., Algers, B., Person, E. \& Andersson, H.K., 2009. Different roughages to organic growing/finishing pigs Influence on activity behaviour and social interactions. Livest. Sci.123, 55-62.

Jordan, D., Zgur, S., Gorjanc, G. \& Stuhec, I. 2008. Straw or hay as environmental improvement and its effect on behawiour and production traits of fattening pigs. Arch. Tierzucht 51, 549-559.

Kishimoto, Y., Wakabayashi, S. \& Takeda, H., 1995. Hypocholesterolomic effect of dietary fibre: relation to intestinal fermentation and bile acid excretion. J. Nutr. Sci. Vitaminology 41, 151-161.

Karpiesiuk, K. \& Falkowski, J., 2008. Reaction of fatteners to different management conditions. Rocz. Nauk. PTZ 4, 65-75. (in Polish, an English abstract).

Karpiesiuk, K., Kozera, W., Bugnacka, D. \& Falkowski, J., 2013. Effect of rearing system conditions of fatteners on meat quality and profile of fatty acids in $m$. longissimus dorsi. Żywność Nauka Technologia Jakość 3, 39-50. (in Polish, an English abstract).

Klont, R.E., Hulsegge, B., Hoving-Bolink, A.H., Gerritzen, M.A., Kurt, E., Winkelman-Goedhart, H.A., de Jong I.C. \& Kranen, R.W., 2001. Relationships between behavioral and meat quality characteristics of pigs raised under barren and enriched housing conditions. J. Anim. Sci. 79, 2835-2843.

Kozera, W., 2007. Fattening efficiency and behaviour patterns of growing-finishing pigs as dependent on housing system and feeding conditions. UWM Olsztyn 128, 1-89. (in Polish, an English abstract).

Kozera, W., Falkowski, J., Bugnacka, D. \& Falkowska, A., 2006. Fattening value and slaughter quality of crossbred (Polish Landrace $x$ Pietrain) pigs fed diets with an increased crude fibre content. Pol. J. Natur. Sci. 20, 205-215.

Lebret, B., 2008. Effects of feeding and rearing systems on growth, carcass composition and meat quality in pigs. Anim. 2, 1548-1558

Lebret, B., Dourmad, J.Y., Mourot, J., Pollet, P.Y. \& Gondret, F., 2014. Production performance, carcass composition, and adipose tissue traits of heavy pigs: Influence of breed and production system. J. Anim. Sci. 92, 3543-3556.

Migdał, W., Koziec, K., Kochanowski, J., Tuz, R., Borowiec, F., Furgał, K. \& Gardzińska, A., 1999. Issue traits of crossbreed fatteners. Med. Wet. 55, 403-407. (in Polish, an English abstract).

Millet, S., Raes, K., Van de Broeck, W., De Smet, S. \& Janssens, G.P.J., 2005. Performance and meat quality of organically versus conventionally fed and housed pigs from weaning till slaughtering. Meat Sci. 69, 335-341.

NRC, 2012. Nutrient Requirements of Swine. The National Academies Press Washington D.C., USA.

Parunović, N., Petrović, M., Matekalo-Sverak, V., Trbović, D., Mijatović, M. \& Radović Č., 2012. Fatty acid profile and cholesterol content of $m$. longissimus of free-range and conventionally reared Mangalitsa pigs. S. Afr. J. Anim. Sci. 42, 101-113.

Pig Nutrient Requirements, 1993. Institute of Animal Physiology and Nutrition. Omnitech Press, Warszawa (in Polish).

Sather, A.P., Jones, S.D.M., Schaefer, A.L., Colyn, J. \& Robertson, W.M., 1997. Feedlot performance, carcass composition and meat quality of free-range reared pigs. Can. J. Anim. Sci. 77, 225-232.

Statistica for Windows, (data analysis software system), ver. 12.5 PL. www.statsoft.com.

Stern, S., Heyer, A., Andersson, H.K., Rydhmer, L. \& Lundsröm, K., 2003. Production results and technological meat quality for pigs in indoor and outdoor rearing systems. Acta Agr. Scand. A-An. 53, 166-174.

Strudsholm, K. \& Hermansen, J.E., 2005. Performance and carcass quality of fully or partly outdoor reared pigs in organic production. Livest. Prod. Sci. 96, 261-268.

Velayudhan, D.E., Kim, I.H. \& Nyachoti, C.M., 2015. Characterization of dietary energy in swine feed and feed ingredients: A review of recent research results. Asian Australas. J. Anim. Sci. 28, 1-13.

Winnicka, A., 2011. Wartości referencyjne podstawowych badań laboratoryjnych w weterynarii. The reference values of basic laboratory tests in veterinary medicine. Ed. SGGW Warszawa. (in Polish). 